\title{
Streamwater Chemistry of Mountain Forest Watersheds in the Bavarian Alps - Changes induced by forest harvesting and natural disturbances
}

\section{Rupert Bäumler, Freising-Weihenstephan}

\section{Introduction}

The mountain forests covering large areas of the Alps have basic ecological and economic functions: they form barriers against avalanches, soil erosion or mass movement, and control water quality and water balance. Besides being the source of economic commodities, they are also important recreational areas. In this light, it would seem that the protection of mountain forests lies in the interest of society in general. However, for several decades now, the Alps have suffered under a continually increasing loss of natural resources by atmospheric pollution and intensive winter and summer tourism.

The aim of this study was to characterise the streamwater chemistry of mountain forest watersheds in the Bavarian Alps. As solutes are one of the most sensitive parameters in terms of ecosystem response, the results should shed light on the present day situation of the forests. Because almost all previous watershed studies were carried out in strongly acidified or polluted ecosystems, the present study will provide data about the dynamics of solutes in well-buffered ecosystems, and thus about the impact of man-made or natural disturbances on the stability of these mountain forests: an absolute necessity for future risk assessment or risk minimisation in such areas. Natural or anthropogenic impact was simulated by forest thinning. This had the advantage of allowing observations to be made on the extent of commercial use in such mountain forest ecosystems without causing severe damage to the manifold functions.

\section{Materials and methods}

Two adjacent south- to southwest facing watersheds (WS) about $50 \mathrm{~km} \mathrm{SW}$ of Munich near the lake "Tegernsee» in the Bavarian Alps were the focus of this study (Fig. 1). Both watersheds have similar site conditions; an important aspect when considering the short monitoring period of four years. A similarity of the watersheds also helps to minimise monitoring differences by spatial heterogeneity. The watersheds cover an area of 4.2 ha (WS1) and 6.3 ha (WS2) with an average slope inclination of $21^{\circ}$ and $19^{\circ}$, respectively. The average horizontal distance between both WS is $350 \mathrm{~m}$. The vertical distance between the weirs at the foot of the watersheds and the ridges is about $180 \mathrm{~m}$. The ridge of WS1 lies at $1210 \mathrm{~m}$ a.s.l., that of WS2 $10 \mathrm{~m}$ higher. Parent materials of the flysch zone are Cretaceous sediments, i.e. sandstone and claystones. Above $1150 \mathrm{~m}$, acidic Cambisols and Podzols have developed from mica-rich sandstone. Downslope, stratified redoximorphic and hydromorphic soils have developed in the clayey parent materials, making the subsoil almost watertight. With $74 \%$ of Picea abies, Piceetum montanum galietosum dominates the vegetation in WS1; in WS2 $71 \%$ of the vegetation is Picea abies. Further tree types are $15 \%$ and $14 \%$ Abies alba, and $11 \%$ and $14 \%$ Fagus sylvatica at WS1 and WS2, respectively. The surrounding mountain peaks rise to 1200-1400 m a.s.l.. A detailed description of the area, including maps and vegetation data, is to be found in MoEsCHKe (1998: 19-33).

Discharge was continuously measured by float level gauges in $90^{\circ}$-V-weirs installed at the foot of the watersheds. A detailed description of the weirs and the gauge stations is given in Breitsameter (1996: 32-34). On a weekly basis, samples were taken from the weir before the water entered the sedimentation traps for the purpose of measuring solute content. Samples for suspended load measurements were taken automatically, depending on discharge (BREITSAMETER 1996: 35-43). The sedimentation traps were cleared twice to thrice a year (Breitsameter 1996: 67). The water samples were filtered using Whatman $\mathrm{GF} / \mathrm{F}$ glass fibre filters $<0.7 \mu \mathrm{m} ; \mathrm{pH}$, conductivity, $\mathrm{NH}_{4}{ }^{+}$and anions were measured after sampling. Cations were determined on a quarterly basis, after samples had been stored at $-15^{\circ} \mathrm{C}$ (BäUMLER 1995: 16-17). It was assumed that changes in the samples' chemistry during storage were negligible (Galloway \& LiKens 1976: 256). Precipitation reactions could not be detected by filtration through $0.05 \mu \mathrm{m}$ cellulose-nitrate filters after storage (B̈̈UMLER 1995: 95-96). Anions and dissolved organic carbon (DOC; UV-oxidation) were determined colorimetrically (Alpkem RFA-300), cations assessed by atomic absorption (Varian SpectrAA 400). Organic anions and acid neutralisation capacity (ANC) were calculated according to OLIVER et al. (1983: 2033-2034) and Driscoll et al. (1987: 226).

Solute monitoring was carried out over four years (1990 to 1993). The mean annual precipitation during this period was $1988 \mathrm{~mm}$, with a maximum in July and minima in autumn and winter (BÄUMLER \& ZECH 1997: 244). The mean runoff was $2.01 \mathrm{~s}^{-1}$ in WS1 and $2.71 \mathrm{~s}^{-1}$ 


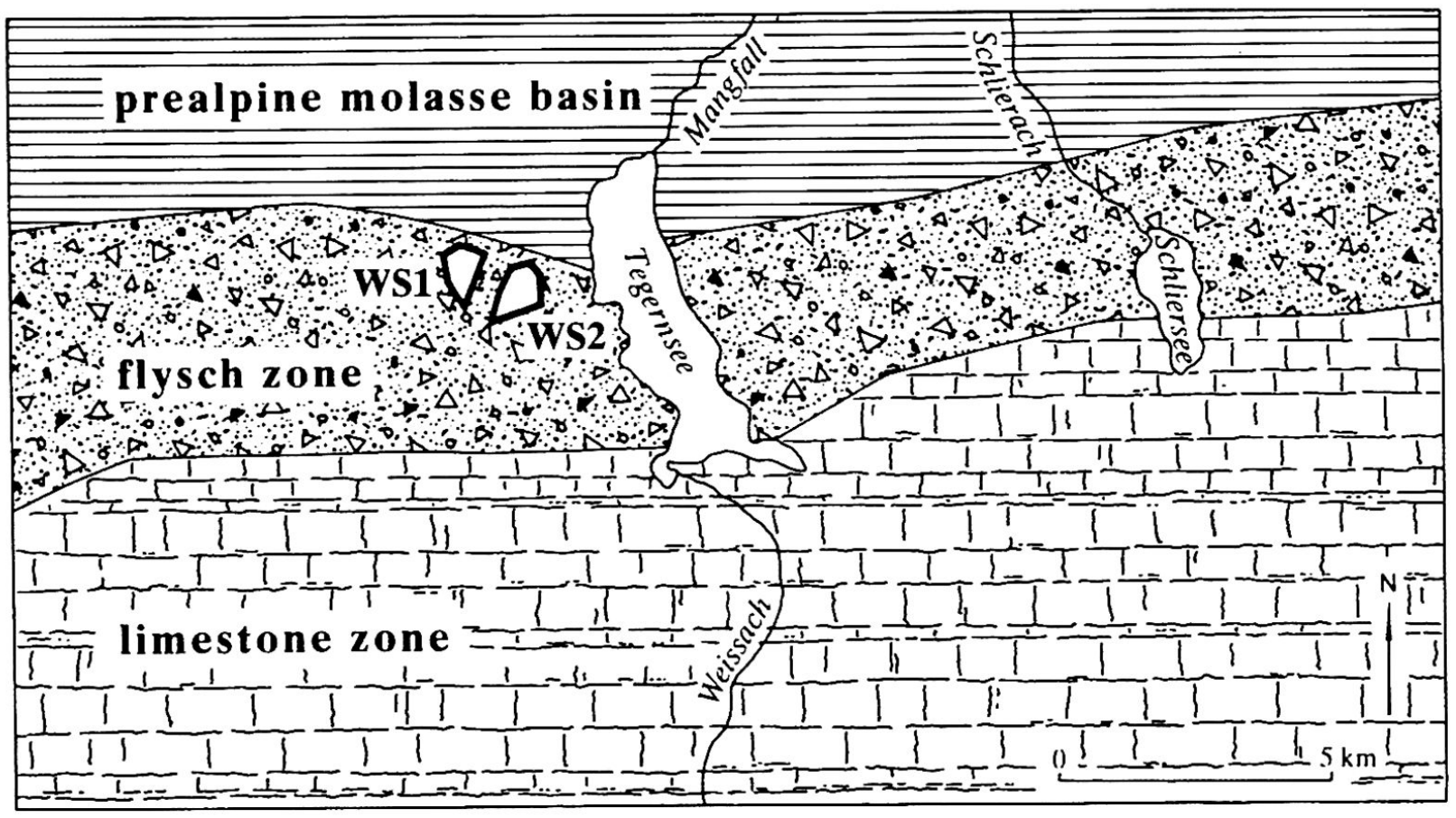

Fig. 1: Location of the study areas WS1 and WS2

Lage der Arbeitsgebiete WS1 und WS2

Localisation des bassins-versants WS1 et WS2 étudiés

Source: according to BreITSAMETER (1996), modified; cartography: V. SCHEURING

in WS2 (1992-1995; MoESCHKe 1998: appendix 23), the mean sediment discharge totalled $1.7 \mathrm{t} \mathrm{ha}^{-1}$ and $1.1 \mathrm{t}$ ha $^{-1}$ respectively (1992-1994; BREITSAMETER 1996: 67), and the suspended load was calculated at $9.3 \mathrm{~g} \mathrm{I}^{-1}$ in WS1 and $4.3 \mathrm{~g} \mathrm{l}^{-1}$ in WS2 (1993-1994; BreITSAMETER 1996: 73).

Natural or anthropogenic disturbances were simulated in October 1992 in WS1 by means of selective harvest (patch cutting method) of $40 \%$ of the 95 years old trees, the disturbance taking place two years into the monitoring period. To minimise soil damage and erosion, stems were removed by cable crane. Residues were left on the ground. WS2 was left as a reference area due to the relatively short monitoring period.

\section{Results and discussion}

Mean monthly precipitation and discharge had a similar pattern (Fig. 2; $r=0.62^{* * *}$, Spearman rank order correlation, $n=74$ ). As with precipitation, maximum discharge occurred in July and minima in autumn and winter. In contrast, the discharge disproportionally increased in April during snowmelt, and strongly decreased in May at the beginning of the growing season, accompanied by increasing temperatures and evapotranspiration rates. In most cases, the water-stage hydrograph rose shortly after precipitation events
(MoEschKe 1998: 102 ff.), showing just how fast the ecosystem reacts. Rainwater was either rapidly transferred directly to the receiving streams, or previously stored water was rapidly exchanged by new rainwater, or both.

It was possible to observe the exchange of stored water by analysing the streamwater chemistry and by comparing input and output rates. The streamwater generally had a soft alkaline reaction with a mean $\mathrm{pH}$ value of 7.8, calcium and bicarbonate dominating (WS2; Tab. 1). The conductivity of the streamwater with $230 \mu \mathrm{S}$ $\mathrm{cm}^{-1}$ was three times higher than the conductivity of soil solutions and precipitation (B̈̈UMLER \& ZECH 1997: 245, and 1998: 233). In particular, $\mathrm{Mg}^{2+}$ values were ten times greater, indicating strong hydrolytic processes in the subsoils and the weathering zone. Concentrations of all other cations and anions were low, except for sulphate values which moved between $1.8 \mathrm{mg} \mathrm{l}^{-1}$ in precipitation and $6.6 \mathrm{mg} \mathrm{l}^{-1}$ in streamwater. The strong export of sulphate is closely linked to the overall reduction of atmospheric S-pollution during the last decade (Krebs \& Moritz 1995: 62 ff.). As a result of the change in equilibrium, sulphates which had accumulated in the soil and in sediments were concurrently released (RUSTAD et al. 1993: $120 \mathrm{ff}$.). The concentration of silicic acid in streamwater was, on the other hand, $40 \%$ less than in the soil solutions, indicating that polymerisation was occurring and that second- 


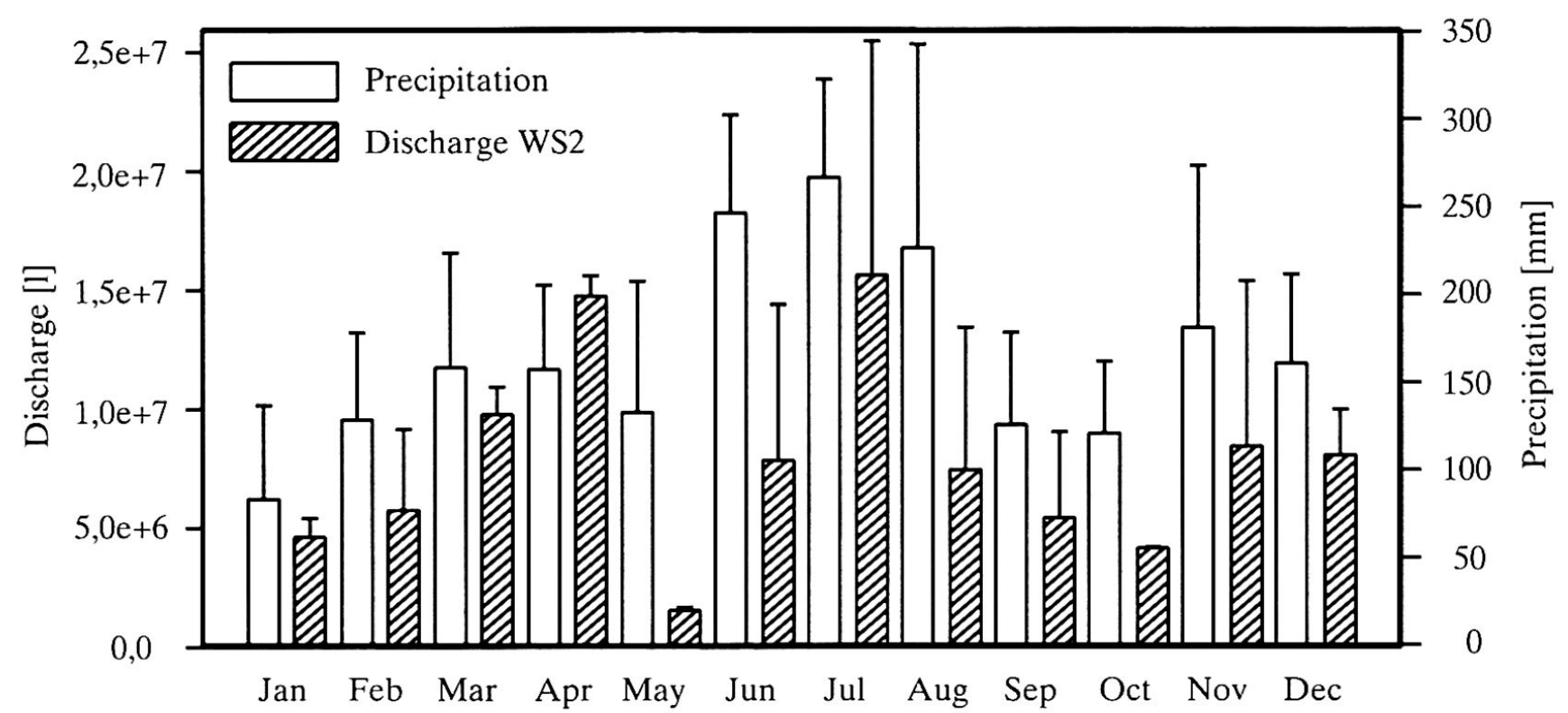

Fig. 2: Mean monthly precipitation ( $\mathrm{mm}$ ) and discharge (l) of the control watershed (WS2) Mittlere monatliche Niederschläge ( $\mathrm{mm}$ ) und Abflussmengen (l) aus dem Kontrolleinzugsgebiet (WS2) Précipitations et débits moyens mensuels du bassin-contrôle (WS2)

ary minerals were being formed in the deeper substratum. The calculation of an equivalent charge of cations and anions showed an anion deficit probably caused by underestimation of bicarbonate. Precipitation reactions monitored after sampling and storage of the samples could not be assessed down to a pore size exclusion of $0.05 \mu \mathrm{m}$ (B̈̈UMLER 1995: 95-96).

The strong variations in the water chemistry along the flowpath from input via soils to export were at least partly caused by differences in subsurface storage time. The longer the storage time, the greater the possibility that the acidity in the system is completely buffered and the greater the chemical changes in the streamwater (DrISCOLL et al. 1987: 235-238). Another reason for the strong variation might be found in the reductive conditions in the headwater areas, the latter covering about $25 \%$ of the total area in both watersheds. Groundwater samples were taken from these headwater areas using porous high-grade steel tubes in order to analyse polycyclic aromatic hydrocarbons (PAH) by means of HPLC (BLESSING 1995: 21-44). As some of the samples had $\mathrm{pH}$ values exceeding 9.0, their sources of origin must partly be the cause of the high $\mathrm{pH}$ values in the streamwater. In addition, the PAH streamwater pattern was exactly the same as the PAH pattern found adsorbed in the hydromorphic soil matrix of the headwater areas, but differing from the well-drained soils (BLEssing 1995: 67-82). Thus, these results too indicate a strong influence of the headwater areas on runoff and streamwater chemistry.
Both watersheds served as areas of «source» and «sink» (Fig. 3). On the sink side, acidity, nitrogen, organic carbon, organic and inorganic pollutants were accumulated. $\mathrm{NH}_{4}{ }^{+}$was more or less completely transformed to nitrate or taken up by biota. Particularly as $\mathrm{NH}_{4}{ }^{+}$strongly promotes soil acidification by the release of protons, both watersheds may in the longterm experience difficulties due to the high mean input rates (Fig. 3; BÄUMLER \& ZECH 1997: 247). At present it appears as if nitrogen is being accumulated, but the pine trees in both watersheds showed signs of nitrogen deficiency (B̈̈UmLER et al. 1995: 32-33). Mean N-deposition rates were $25 \mathrm{~kg} \mathrm{ha}^{-1} \mathrm{a}^{-1}$, and a further 8-9 t ha $^{-1} \mathrm{~N}$ were stored in the soils (BÄUmLER et al. 1995: $35)$. Considering trees supply themselves usually with about $10 \mathrm{~kg} \mathrm{ha}^{-1} \mathrm{~N}$ per year, there should have been more than enough $\mathrm{N}$ in the ecosystem to support the vegetation. The $\mathrm{N}$-deficiency registered in both watersheds is therefore probably an indication that the gaseous losses of $\mathrm{N}$ through nitrification and denitrification processes occur faster than $\mathrm{N}$ uptake in the ecosystem. And indeed, the site conditions of both watersheds promote high denitrification rates: SW-facing slopes, sufficient organic carbon sources for microorganisms and redoximorphic or hydromorphic soil properties in more than $60 \%$ of all soils (Groffman \& Tiedje 1989: $615 \mathrm{ff}$.).

The watershed as a «source» may be seen in the high rate of export of silicic acid, alkali and alkaline earth cations and bicarbonate (Fig. 3). Discharge of chloride was $31 \%$ higher than the input rates calculated accord- 


\begin{tabular}{|c|c|c|}
\hline & WS2 & Export \\
\hline $\mathrm{pH}$ & 7.8 & \\
\hline$\left[\mathrm{H}^{+}\right]\left(\mu \mathrm{eq} \mathrm{l}^{-1}\right)$ & 0.014 & $0.21 \mathrm{~g} \mathrm{ha}^{-1} \mathrm{a}^{-1}$ \\
\hline $\mathrm{Ca}^{2+}\left(\mathrm{mg} \mathrm{l}^{-1}\right)$ & 28.7 & $426.6 \mathrm{~kg} \mathrm{ha}^{-1} \mathrm{a}^{-1}$ \\
\hline $\mathrm{K}^{+}\left(\mathrm{mg} \mathrm{l}^{-1}\right)$ & 0.7 & $10.3 \mathrm{~kg} \mathrm{ha}^{-1} \mathrm{a}^{-1}$ \\
\hline $\mathrm{Mg}^{2+}\left(\mathrm{mg} \mathrm{l}^{-1}\right)$ & 3.5 & $51.7 \mathrm{~kg} \mathrm{ha}^{-1} \mathrm{a}^{-1}$ \\
\hline $\mathrm{Na}^{+}\left(\mathrm{mg} \mathrm{l}^{-1}\right)$ & 1.6 & $23.0 \mathrm{~kg} \mathrm{ha}^{-1} \mathrm{a}^{-1}$ \\
\hline $\mathrm{NH}_{4}^{-}\left(\mathrm{mg} \mathrm{l}^{-1}\right)$ & 0.02 & $0.30 \mathrm{~kg} \mathrm{ha}^{-1} \mathrm{a}^{-1}$ \\
\hline $\mathrm{NO}_{3}^{-}\left(\mathrm{mg} \mathrm{l}^{-1}\right)$ & 3.3 & $48.6 \mathrm{~kg} \mathrm{ha}^{-1} \mathrm{a}^{-1}$ \\
\hline $\mathrm{SO}_{4}^{2-}\left(\mathrm{mg} \mathrm{l}^{-1}\right)$ & 6.5 & $97.3 \mathrm{~kg} \mathrm{ha}^{-1} \mathrm{a}^{-1}$ \\
\hline $\mathrm{H}_{4} \mathrm{SiO}_{4}\left(\mathrm{mg} \mathrm{l}^{-1}\right)$ & 4.2 & $62.0 \mathrm{~kg} \mathrm{ha}^{-1} \mathrm{a}^{-1}$ \\
\hline $\mathrm{PO}_{4}^{3-}\left(\mu \mathrm{g} \mathrm{l}^{-1}\right)$ & 16.2 & $0.24 \mathrm{~kg} \mathrm{ha}^{-1} \mathrm{a}^{-1}$ \\
\hline $\mathrm{Cl}^{-}\left(\mathrm{mg} \mathrm{l}^{-1}\right)$ & 0.8 & $11.3 \mathrm{~kg} \mathrm{ha}^{-1} \mathrm{a}^{-1}$ \\
\hline $\mathrm{HCO}_{3}^{-}\left(\mathrm{mg} \mathrm{l}^{-1}\right)$ & 50.7 & $753.0 \mathrm{~kg} \mathrm{ha}^{-1} \mathrm{a}^{-1}$ \\
\hline $\operatorname{DOC}\left(\mathrm{mg} \mathrm{l}^{-1}\right)$ & 2.0 & $29.7 \mathrm{~kg} \mathrm{ha}^{-1} \mathrm{a}^{-1}$ \\
\hline $\mathrm{Al}\left(\mathrm{mg} \mathrm{l}^{-1}\right)$ & 0.4 & $5.4 \mathrm{~kg} \mathrm{ha}^{-1} \mathrm{a}^{-1}$ \\
\hline Conductivity $\left(\mu \mathrm{S} \mathrm{cm}^{-1}\right)$ & 230.6 & \\
\hline ANC $\left(\mu\right.$ eq $\left.1^{-1}\right)$ & 3156.6 & \\
\hline
\end{tabular}

Table 1: Volume weighted means for $\mathrm{pH}$, ion concentration, DOC $(<0.7 \mu \mathrm{m})$, conductivity, acid neutralisation capacity (ANC) in the streamwater, and export rates from the control watershed WS2 during the monitoring period (Nov. 1989-Dec. 1993)

Volumen-gewichtete Mittelwerte von pH, Ionenkonzentrationen, DOC $(<0.7 \mu \mathrm{m})$, elektrischer Leitfähigkeit, Säureneutralisationskapazität $(A N C)$ im Fliessgewässer der Kontrollfäche WS2 und Austragsraten aus dem Einzugsgebiet während der Messperiode (Nov. 1989-Dez. 1993)

Valeurs moyennes rapportées au volume total du $\mathrm{pH}$, des concentrations en ions, du DOC $(<0.7 \mu \mathrm{m})$, de la conductivité, de la capacité de neutralisation des acides $(A N C)$ de l'eau de ruissellement, et des débits d'exportation du bassin-contrôle WS2 durant la période d'étude

ing to evapotranspiration rates. Only aluminium had a balanced ratio between watershed input and output. The high export rates are linked to two buffering processes in connection with deposited and internally produced acidity. The first process is the cation exchange, a fast reaction taking place mainly in the topsoil horizons. The second is silicate hydrolysis. Compared to cation exchange, the latter is a slower reaction, thus acquiring a longer period of contact between precipitation water and the mineral matrix. During rainfall, the water stored below ground percolates to lower horizons, the pores in the upper levels being replaced with fresh rainwater. Evidence for this were the weak concentration fluctuations of most of the solutes, especially in comparison to precipitation and soil solution chemistry (Fig. 4; BÄUMLER \& ZECH 1997: 246, and 1998: 235). As short periods of contact between water and the soil matrix generally cause strong fluctuations of streamwater solutes (JACKs et al.1987:284), the cycle of solutes for both watersheds indicate a tendency towards internal sorption, precipitation and buffering processes. Moreover, similar solute curves during the pre-event period meant that impacts registered as a result of selective harvest would apply to both watersheds (Fig. 4).

Time series for different solutes and concentrations also delivered the following information: $\mathrm{pH}$ values continually decreased, indicating an increasing acidity load (Fig. 4; $\mathrm{pH}_{\mathrm{wS} 1}=8.23-0.01 * \mathrm{t}$ and $\mathrm{pH}_{\mathrm{wS} 2}=8.14-0.01 * \mathrm{t}$; Bäumler 1995: 105-107). Part of the acidity seems to have been directly and rapidly transferred to the receiving streams by interflow. Increasing acidification could also be detected in connection with alkali and alkaline earth cation mobilisation, such as calcium, the acid neutralisation capacity of the streamwater thereby 


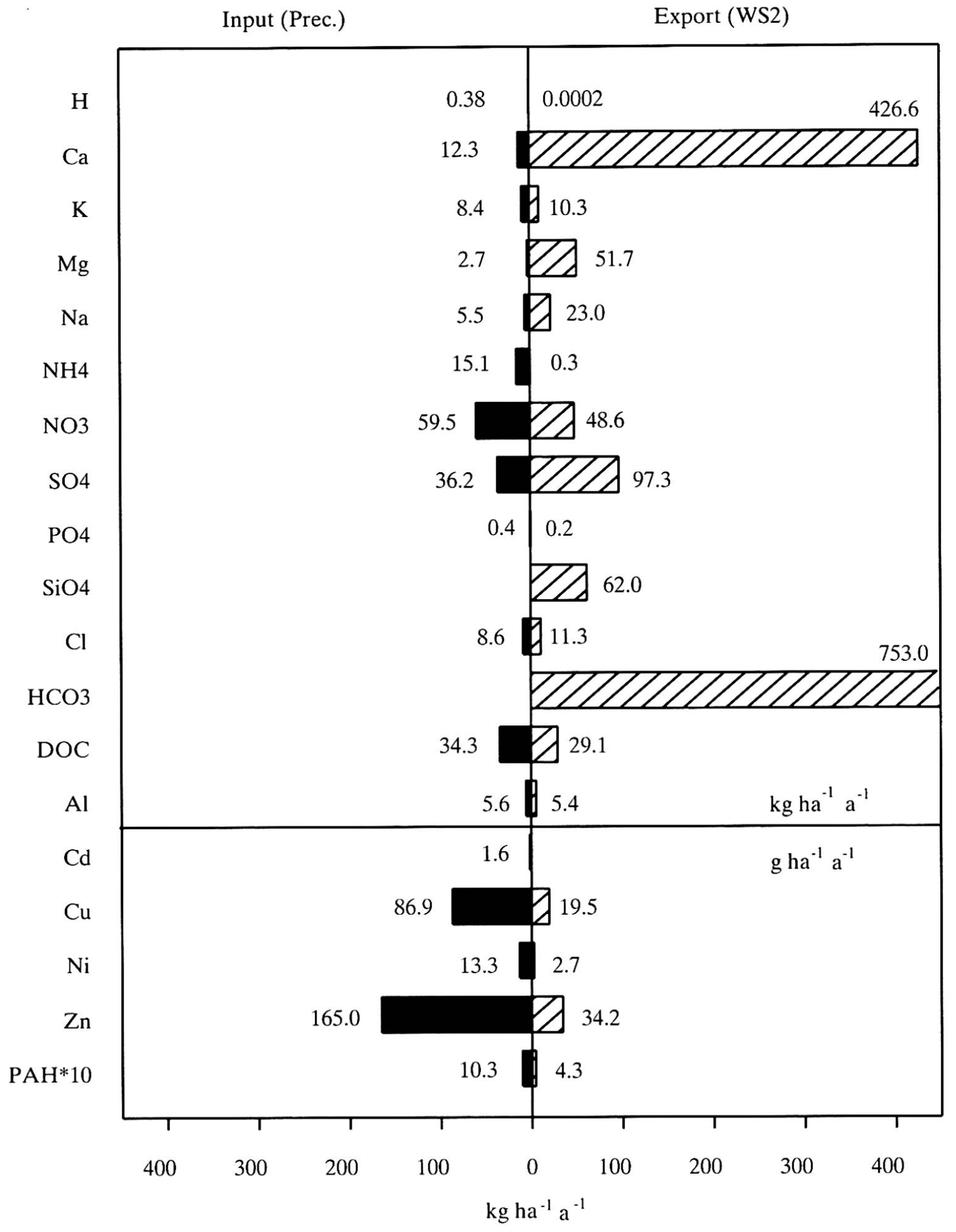

Fig. 3: Solute import and export in WS2 via precipitation and streamwater (Nov. 1989-Dec. 1993)

Eintragsraten gelöster Stoffe über die Niederschläge und Austragsraten über den Vorfluter von WS2 (Nov. 1989-Dez. 1993)

Débit de solutés entrants par précipitation et évacués par l'eau de ruissellement pour le bassin WS2 (nov. 1998-déc. 1993) 


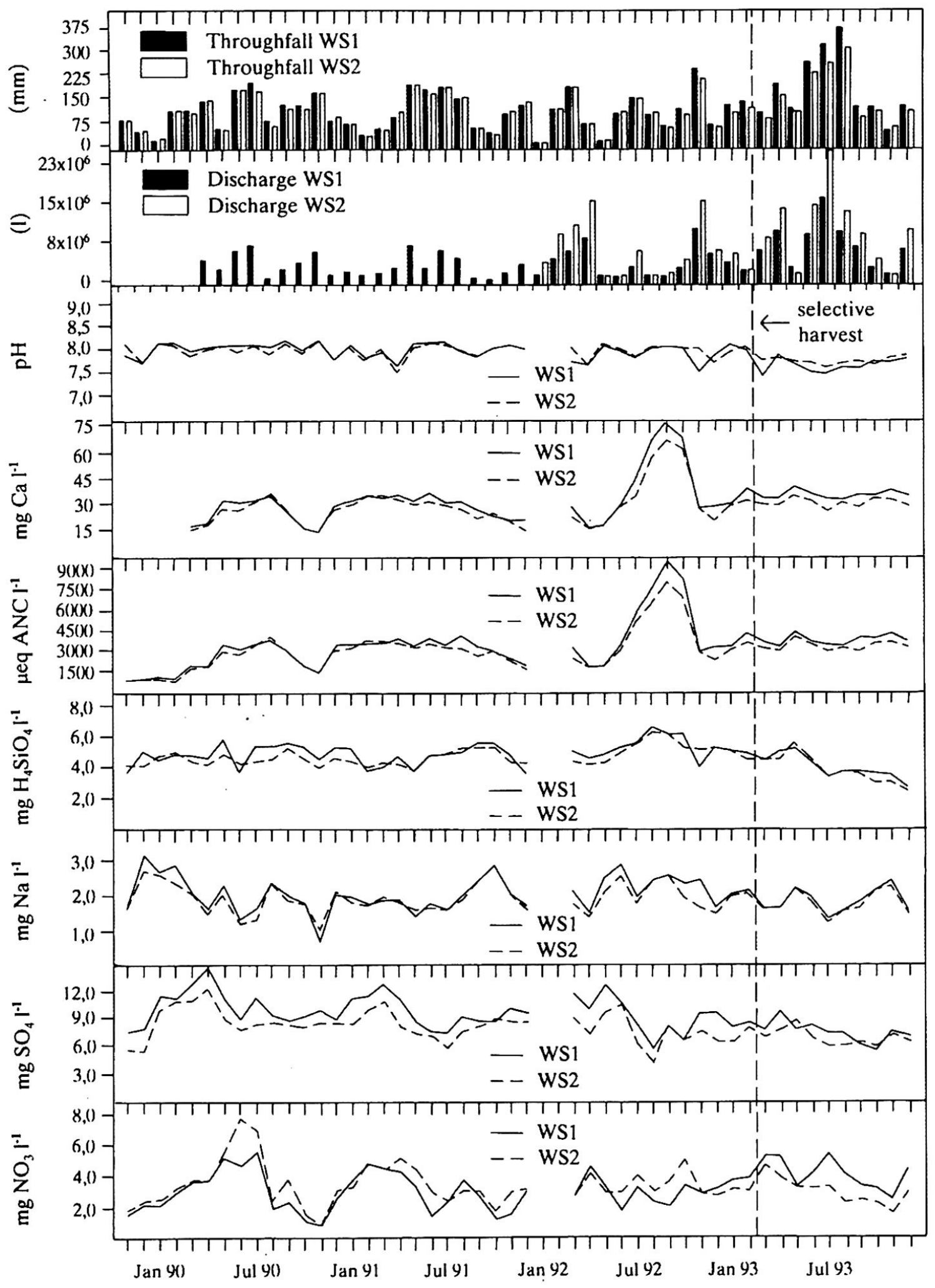

Fig. 4: Time series of precipitation, discharge, and mean monthly $\mathrm{pH}, \mathrm{Ca}^{2+}, \mathrm{H}_{4} \mathrm{SiO}_{4}, \mathrm{Na}^{+}, \mathrm{SO}_{4}{ }^{2 \cdot}$ and $\mathrm{NO}_{3}$ concentrations and acid neutralization capacity (ANC) in WS1 (experimental area) and WS2 (control) streamwater. Zeitlicher Verlauf von Niederschlag, Abfluss und den mittleren monatlichen Konzentrationen von $\mathrm{pH}, \mathrm{Ca}^{2+}$, $\mathrm{H}_{4} \mathrm{SiO}_{4}, \mathrm{Na}^{+}, \mathrm{SO}_{4}^{2}, \mathrm{NO}_{3}$ und Säureneutralisationskapazität (ANC) im Fliessgewässer von WS1 (Versuchsfäche) und WS2 (Kontrolle)

Evolution des concentrations moyennes mensuelles en $\mathrm{Ca}^{2+}, \mathrm{H}_{4} \mathrm{SiO}_{4}, \mathrm{Na}^{+}, \mathrm{SO}_{4}^{2}, \mathrm{NO}_{3}$, de la capacité de neutralisation des acides et du pH dans l'eau de ruissellement de WS1 (bassin expérimental) et WS2 (bassin-contrôle)

Draft: R. BÄUMLER, diagram: V. SCHEURING 


\begin{tabular}{|lcccc|}
\hline & \multicolumn{2}{c}{ before selective harvest } & \multicolumn{2}{c|}{ after selective harvest } \\
& WS1 & WS2 (control) & WS1 & WS2 (control) \\
\hline $\mathrm{pH}$ & 8.03 & 7.91 & $7.63^{\mathrm{a}}$ & $7.81^{\mathrm{b}}$ \\
{$\left[\mathrm{H}^{+}\right]\left(\mu \mathrm{eq} \mathrm{l}^{-1}\right)$} & 0.009 & 0.011 & 0.021 & 0.014 \\
$\mathrm{Ca}^{2+}$ & $30.03^{\mathrm{a}}$ & $29.36^{\mathrm{b}}$ & $32.20^{\mathrm{a}}$ & $28.56^{\mathrm{b}}$ \\
$\mathrm{Mg}^{2+}$ & $4.05^{\mathrm{a}}$ & $5.15^{\mathrm{b}}$ & $3.61^{\mathrm{a}}$ & $3.08^{\mathrm{b}}$ \\
$\mathrm{K}^{+}$ & $0.85^{\mathrm{a}}$ & $1.04^{\mathrm{b}}$ & $0.88^{\mathrm{a}}$ & $0.61^{\mathrm{b}}$ \\
$\mathrm{Na}^{+}$ & $1.60^{\mathrm{a}}$ & $1.66^{\mathrm{b}}$ & $1.81^{\mathrm{a}}$ & $1.53^{\mathrm{b}}$ \\
$\mathrm{NH}_{4}^{+}$ & $0.05^{\mathrm{a}}$ & $0.05^{\mathrm{b}}$ & $0.19^{\mathrm{a}}$ & $0.01^{\mathrm{b}}$ \\
$\mathrm{NO}_{3}^{-}$ & $3.50^{\mathrm{a}}$ & $3.96^{\mathrm{b}}$ & $4.27^{\mathrm{a}}$ & $3.11^{\mathrm{b}}$ \\
$\mathrm{SO}_{4}^{2-}$ & $9.14^{\mathrm{a}}$ & $7.03^{\mathrm{b}}$ & $8.01^{\mathrm{a}}$ & $6.44^{\mathrm{b}}$ \\
$\mathrm{PO}_{4}^{3-}\left(\mu \mathrm{g} \mathrm{l}^{-1}\right)$ & 6.45 & 4.02 & $45.76^{\mathrm{a}}$ & $19.02^{\mathrm{b}}$ \\
$\mathrm{H}_{4} \mathrm{SiO}_{4}$ & $4.71^{\mathrm{a}}$ & $4.70^{\mathrm{b}}$ & $4.09^{\mathrm{a}}$ & $4.05^{\mathrm{b}}$ \\
$\mathrm{Cl}^{-}$ & 0.79 & 0.76 & $1.11^{\mathrm{a}}$ & $0.76^{\mathrm{b}}$ \\
$\mathrm{HCO}_{3}^{-}$ & $69.10^{\mathrm{a}}$ & $58.66^{\mathrm{b}}$ & $52.96^{\mathrm{a}}$ & $48.88^{\mathrm{b}}$ \\
$\mathrm{DOC}^{\mathrm{b}}$ & $2.48^{\mathrm{a}}$ & $1.35^{\mathrm{b}}$ & $3.39^{\mathrm{a}}$ & $2.10^{\mathrm{b}}$ \\
$\mathrm{Al}^{\mathrm{b}}$ & 0.73 & 0.60 & $0.77^{\mathrm{a}}$ & $0.28^{\mathrm{b}}$ \\
$\mathrm{Conduct}^{\mathrm{b}}\left(\mu \mathrm{S} \mathrm{cm}^{-1}\right)$ & $256.3^{\mathrm{a}}$ & $234.3^{\mathrm{b}}$ & $242.6^{\mathrm{a}}$ & $223.3^{\mathrm{b}}$ \\
$\mathrm{ANC}^{\mathrm{b}}\left(\mu \mathrm{eq} \mathrm{l}^{-1}\right)$ & 3272.0 & 3486.6 & 3451.7 & 3078.4 \\
\hline
\end{tabular}

Values followed by different letters $\left({ }^{a},{ }^{b}\right)$ within one row are significantly different $(\mathrm{p}<0.01)$ (Wilcoxon matched pairs test).

Table 2: Volume weighted means $\left(\mathrm{mg}^{-1}\right)$ for $\mathrm{pH}$, ion concentration, conductivity, DOC and ANC in the streamwater of WS1 and WS2 before and after the selective harvest (Nov. 1989-Oct. 1992 and Nov. 1992-Dec. 1993) Volumen-gewichtete Mittelwerte ( $\mathrm{mg} \mathrm{l}^{-1}$ ) von $\mathrm{pH}$, Ionenkonzentrationen, elektrischer Leitfähigkeit, DOC und ANC im Fliessgewässer von WS1 und WS2 vor und nach dem forstlichen Eingriff (Nov. 1989-Okt. 1992 und Nov. 1992-Dez. 1993)

Valeurs moyennes rapportées au volume total $\left(m g 1^{-1}\right)$ du $\mathrm{pH}$, des concentrations en ions, du DOC, de la conductivié et de l'ANC des eaux de ruissellement des bassins WS1 et WS2 avant et après l'intervention sélective (nov. 1989-oct. 1992 et nov. 1992-déc. 1993)

increasing. The aforementioned mobilisation is a substage of streamwater acidification, persistent mobilisation leading to long-term ecological consequences, for example through the release of toxic aluminium compounds (STEINBERG et al. 1984: 4 ff.). Observations could also be made in connection with $\mathrm{Ca}$ and nitrogen. Ca release peaked in the summer of 1992. This could be associated with warm and dry climatic conditions during the year, conditions which deviated by $25 \%$ from long-term means. The Ca boost induced concentration effects and an acidification peak, concurrently releasing and subsequently leaching alkali and alkaline earth cations and $\mathrm{HCO}_{3}$. Nitrate concentrations increased in spring during snowmelt. First evidence on the effects of the selective harvest were also noticeable. Mean nitrate concentrations in the streamwater were significantly higher in the control area during the pre-event period. The situation completely changed after the disturbance with a significant mobilisation of nitrate in the experimental watershed WS1 (Fig. 4, Tab. 2).

\section{Effects of forest use or natural disturbance}

Except for $\mathrm{DOC}$ and $\mathrm{Al}$, discharge rates of all solutes were higher during the pre-event period in WS2. The differences between the two watersheds were mainly caused by differences in area, hydraulic properties and flow paths, with a lower subsurface water storage 
before

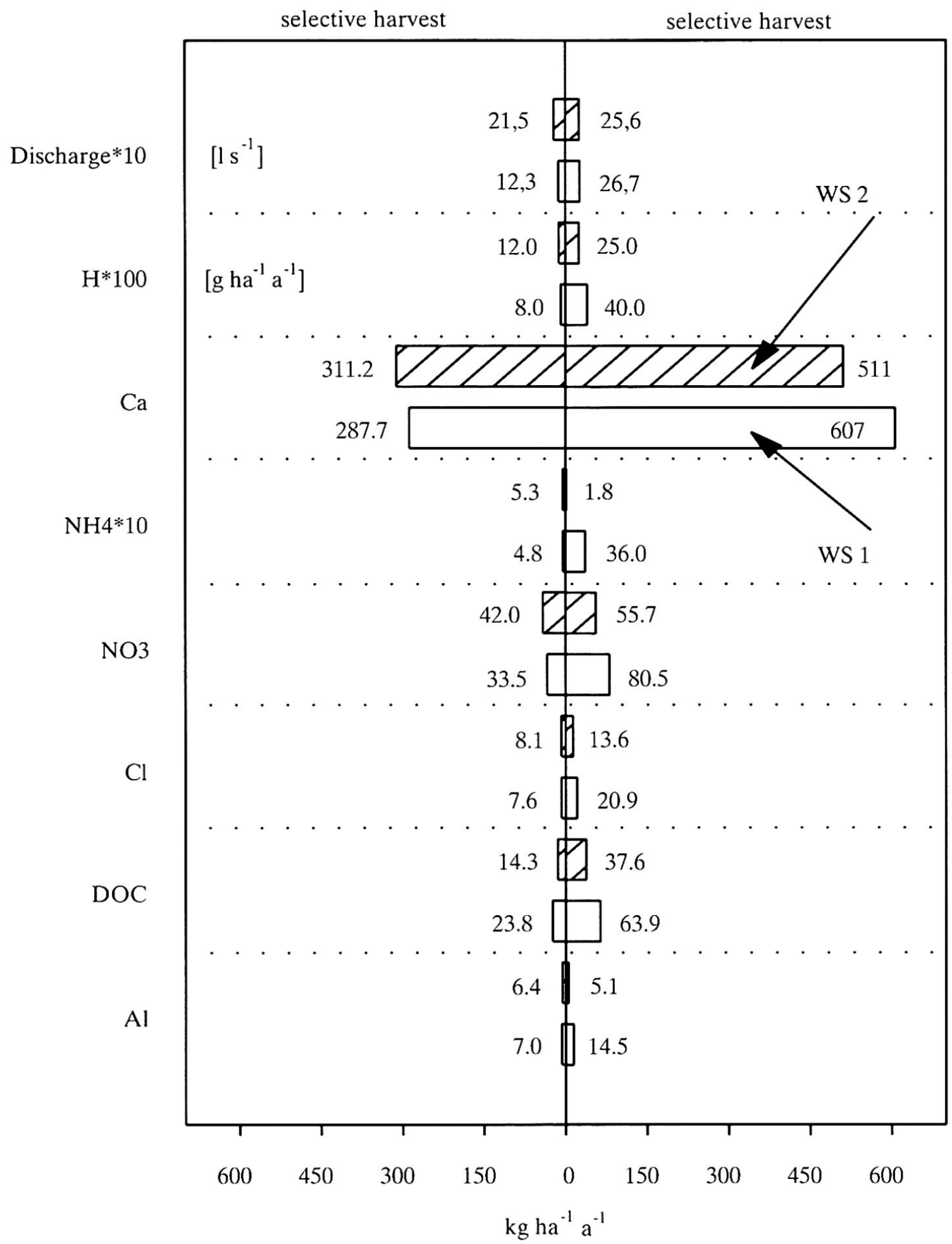

Fig. 5: Export of solutes from WS1 and WS2 via streamwater before and after the selective harvest Austragsraten über die Fliessgewässer aus WS1 und WS2 vor und nach dem forstlichen Eingriff Débit d'évacuation par l'eau de ruissellement dans les bassins WS1 et WS2 avant et après l'intervention sélective 


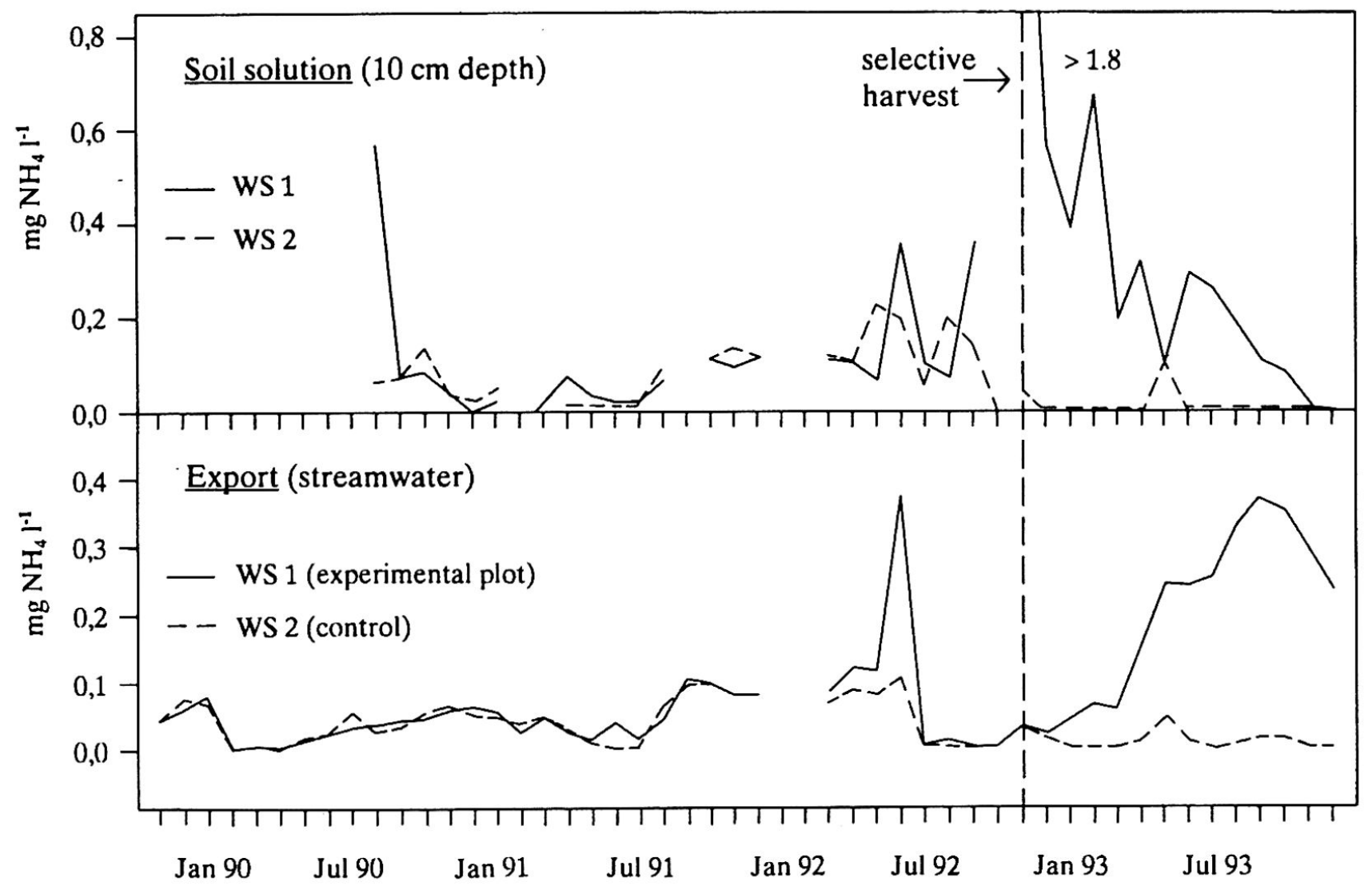

Fig. 6: Time series of mean monthly $\mathrm{NH}_{4}{ }^{+}$concentrations in the soil solution at a depth of $10 \mathrm{~cm}$ and in the streamwater of WS1 and WS2 (1990-1993)

Zeitlicher Verlauf der mittleren monatlichen Konzentrationen von $\mathrm{NH}_{+}^{+}$in der Bodenlösung in $10 \mathrm{~cm}$ Tiefe und im Fliessgewässer von WS1 und WS2 (1990-1993)

Evolution des précipitations, des débits moyens mensuels et des concentrations moyennes mensuelles de $\mathrm{NH}_{+}^{+}$dans des solutions du sol à profondeur de $10 \mathrm{~cm}$, et dans l'eau de ruissellement des bassins-versants WS1 et WS2 avant et après l'intervention sélective

Draft: R. BÄUMLER, diagram: V. SCHEURING

capacity in WS2 (MoEschKe 1998: 164 ff.). The differences may be highlighted by a comparison of the export rates of selected solutes from both watersheds before and after the selective harvest (Fig. 5). Peak flow in WS1 increased by about $30 \%$ after the selective harvest (Fig. 4; MoEschKe 1998: 127 ff.). At the same time, the export rates of all solutes increased beyond the values of the control watershed (Fig. 5). The mobilisation of solutes can be linked directly to the reduced nutrient uptake capacity of the roots and to enhanced mineralisation associated with the $40 \%$ selective harvest. The greatest changes were recorded for protons, aluminium and $\mathrm{N}$ fractions. For example, ammonium concentrations and export rates were similar in both watersheds during the pre-event period. After the disturbance, these decreased in WS2, whereas they increased sevenfold in the experimental watershed. In comparison to the pre-event period, export rates for $\mathrm{H}^{+}, \mathrm{Ca}^{2+}, \mathrm{NO}_{3}$, and DOC also increased in WS2, even though to a lesser extent than in WS1. This was due to the high precipitation rates in 1993, the mean annual precipitation being exceeded by $500 \mathrm{~mm}$ and the total for 1992 by about $800 \mathrm{~mm}$.

On the basis of the soil solution and streamwater time series for ammonium, dominant processes in the watersheds could be identified (Fig. 6). The $\mathrm{NH}_{4}{ }_{4}^{+}$concentration in the topsoil solution of WS1 increased dramatically immediately after selective harvest as root uptake processes had been disturbed. Thereafter, the concentrations continually decreased as nitrification and microbial immobilisation processes took over, indicating a rapid adaptation of soil biota to the new site conditions. No changes were registered in the control watershed and in soil solutions at depths of $30 \mathrm{~cm}$ and $50 \mathrm{~cm}$ (B̈̈UmLER \& ZeCH 1998: 235). The opposite trend was observed in the streamwater, the concentrations gradually increasing. The maximum registered in September 1993 was not reflected in the soil solution concentrations observed at a depth of $10 \mathrm{~cm}$. A prob- 
able explanation lies in the slow release of $\mathrm{NH}_{4}{ }^{+}$from expiring roots of the cut trees into the subsoil horizons. Simultaneously, interflow also washed some of the $\mathrm{NH}_{4}{ }^{+}$into the streamwater before it had a chance to be in extended contact with the biotic and abiotic soil matrix. The changes observed in the soil solution returned to normal within a year from the disturbance, indicating that forest management has, as practised here, little effect on the stability of these mountain forests. Similar results are to be found in Londo et al. (1999: 639 ff.) in connection with the effects different degrees of forest harvesting have on the carbon cycle.

Individual solutes, however, were influenced by processes occurring at the same time as the ecosystem was digesting the effects of forest thinning. Natural or anthropogenic disturbances usually induce an increased acidity load in forest ecosystems (ULRICH 1984: $217 \mathrm{ff}$.). In the study area, mobilised acidity was more or less completely and rapidly buffered by cation exchange so that no fluctuations in the silicic acid time series could be observed (Fig. 3). After the selective harvest, $\mathrm{H}_{4} \mathrm{SiO}_{4}$ in both watersheds decreased by $10 \%$. Unlike the fast reaction time of cation exchange, silicate hydrolysis was too slow to completely compensate enhanced acidity. The release of $\mathrm{Mg}$ was probably linked to silicate hydrolysis and to weathering processes in the deeper substratum. This could explain why $\mathrm{Mg}^{2+}$ concentrations decreased in WS1 due to enhanced discharge after the disturbance leading to a higher dilution (Tab.2).

Similar results were observed for sulphate: the mean concentrations decreasing by about $10 \%$ after forest thinning without evidence of differences between the watersheds (Fig. 3). According to MoEsCHKE (1998: 130-163), no changes in the base flow of WS1 were recorded during the first year after selective harvest. Thus, the subsurface water storage capacity appears to have been unaffected, the headwater areas being the main controlling element. The headwater areas also control the dynamics of sulphate by initialising redox processes. Consequently, $\mathrm{SO}_{4}{ }^{2-}$ behaviour should remain constant in both watersheds before and after the disturbance.

\section{Conclusions}

Solute dynamics were studied in the runoff of two mountain forest watersheds in the Bavarian Alps, the focus being on ecosystem stability under current pollution levels and in situations of man-made or natural disturbances. Discharge and output frame the total watershed, whereas individual subareas and subsystems affect streamwater chemistry and export rates in a ratio equivalent to their contribution to the discharge total.
A close correlation was found between precipitation and discharge. However, precipitation did not immediately enter the streamwater, but was stored for long periods to be replaced by further rainfall, thus enabling buffering of acidity. The strong output of alkali and alkaline earth cations and silicic acid underlines the situation described above. The almost complete buffering of acidity and the high input rates of ammonium could in the long-term lead to soil degradation and streamwater acidification in these mountain forest ecosystems.

$40 \%$ of tree stem volume was removed from one of the watersheds after a monitoring period of about two years (patch cutting method) in order to make observations on the stability of these ecosystems in situations of natural or man-made disturbances. In comparison to the control watershed, discharge and export rates strongly increased due to enhanced mineralisation, acidification and a reduced uptake of water and nutrients. The effects were however, rapidly buffered by cation exchange processes. Except for nitrate, the changes in the streamwater chemistry returned to preevent conditions within a year. Even runoff returned to pre-event averages by 1994 (MOESCHKE 1998: appendix 23). Sediment discharge also strongly decreased from $4.3 \mathrm{t} \mathrm{ha}^{-1}$ in 1993 to $0.7 \mathrm{t} \mathrm{ha}^{-1}$ in 1994. These values were however, still above the sediment output values of the control area WS2 ( $0.3 \mathrm{t} \mathrm{ha}^{-1}$; BREITSAMETER 1996: $67)$. The conclusion may be drawn that the extent and manner of forest harvesting tested in this study affects the forest ecosystem to an acceptable degree. Thus, up to $40 \%$ of the trees in the flysch zone of the Bavarian Alps may be used for economic purposes without fear of endangering the manifold functions of these mountain forest ecosystems.

\section{References}

Bäumler, R., Goerttler, T. \& W. Zech (1995): Nährelement- und Schwermetallgehalte in den Nadeln von Fichten und Tannen eines Bergmischwaldes auf Flysch (Tegernseer Alpen). - In: Forstwissenschaftliches Centralblatt 114: 30-39.

BäUmLeR, R. (1995): Dynamik gelöster Stoffe in verschiedenen Kompartimenten kleiner Wassereinzugsgebiete in der Flyschzone der Bayerischen Alpen Auswirkungen eines geregelten forstlichen Eingriffs. = Bayreuther Bodenkundliche Berichte 40, Bayreuth: 1-133.

BäUMLeR, R. \& W. ZeCH (1997): Atmospheric deposition and impact of forest thinning on the throughfall of mountain forest ecosystems in the Bavarian Alps. - In: Forest Ecology and Management 95: 243-251.

BÄUMLER, R. \& W. ZeCH (1998): Impact of forest use on the soil solution chemistry of mountain forest ecosystems in the Bavarian Alps. - In: Forest Ecology and Management 108: 231-238. 
Blessing, U.(1995): Kennzeichnung der PAK-Dynamik zweier Kleineinzugsgebiete im Flysch. - = Bayreuther Bodenkundliche Berichte 50, Bayreuth: 1-96.

Breitsameter, J. (1996): Untersuchungen zum Feststoffaustrag aus unterschiedlich dicht bewaldeten Kleineinzugsgebieten im Flysch und in den Kalkalpen der Tegernseer Berge. - = Forstliche Forschungsberichte München 154, München: 1-154.

Driscoll, C.T., Wyskowski, B.J., Cosentini, C.C. \& M.E. Sмiтh (1987): Processes regulating temporal and longitudinal variations in the chemistry of a low-order woodland stream in the Adirondack region of New York. - In: Biogeochemistry 3: 225-241.

Galloway, J.N. \& G.E. LiKENS (1976): Calibration of collection procedures for the determination of precipitation chemistry. - In: Water, Air, and Soil Pollution 6: 241-258.

Groffman, P.M. \& J.M. Tiedje (1989): Denitrification in north temperate forest soils: spatial and temporal patterns at the landscape and seasonal scales. - In: Soil Biology and Biochemistry 21: 613-620.

Jacks, G., Olofsson, E. \& G. Werme (1987): An acid surge in a well-buffered stream. - In: Ambio 16:282-285. Krebs, M. \& K. Moritz (1995): Deposition von Luftschadstoffen in Waldgebieten Bayerns. - In: Bayerisches Landesamt für Wasserwirtschaft (Hrsg.): Grundwasserversauerung durch atmosphärische Deposition, - Informationsbericht des Bayerischen Landesamtes für Wasserwirtschaft 3: 57-70.

Londo, A.J., Messina, M.G. \& S.H. Schoenholtz (1999): Forest harvesting effects on soil temperature, moisture, and respiration in a bottomland hardwood forest. - In: Soil Science Society of America Journal 63: 637-644.

MoeschKe, H. (1998): Abflussgeschehen im Bergwald - Untersuchungen in drei bewaldeten Kleineinzugsgebieten im Flysch der Tegernseer Berge. $-=$ Forstliche Forschungsberichte München 169, München: 1-206.

Oliver, B.G., Thurman, E.M. \& R.L. Malcolm (1983):

The contribution of humic substances to the acidity of colored natural waters. - In: Geochimica et Cosmochimica Acta 47: 2031-2035.

Rustad, L.E., Fernandez, I.J., Fuller, R.D., David, M.B., Nodvin, S.C. \& W.A. Halteman (1993): Soil solution response to acidic deposition in a northern hardwood forest. - In: Agriculture, Ecosystem and Environment 47: 117-134.

Steinberg, C., Meier, R., Emeis-Schwarz, H., KrauseDellin, D. \& K. Arzet (1984): Versauerung des Großen Arbersee, dokumentiert durch paläolimnologische Untersuchungen. - In: Vom Wasser 63: 35-56.

ULRICH, B. (1984): Ion cycle and forest ecosystem stability. - In: ÅGREN, G.I. (Hrsg.): State and change of forest ecosystems - Indicators in current research. - = Department of Ecology and Environmental Research Report 13, Swedish University of Agricultural Science: 207-233.
Summary: Streamwater Chemistry of Mountain Forest Watersheds in the Bavarian Alps - Changes induced by forest harvesting and natural disturbances

The streamwater chemistry in two mountain forest watersheds in the Bavarian Alps is described. A close correlation was found to exist between precipitation and runoff. However, the rainwater was to a great part first stored in the ecosystem, to be exchanged by new rainwater after each rainfall event, thus enabling system buffering. An almost complete buffering of acidity could be identified due to the strong watershed output of alkali and alkaline earth cations and silicic acid. On the other hand, protons, organic carbon, nitrogen, organic and inorganic pollutants were accumulated in the ecosystem.

$40 \%$ of tree stem volume was removed from one of the watersheds after a monitoring period of about two years (patch cutting method) in order to make observations on the stability of these ecosystems in situations of natural or man-made disturbances. Runoff and export rates strongly increased in the first year after the disturbance due to enhanced mineralisation, acidification, and a reduced uptake of nutrients and water. Except for nitrate, the changes returned to pre-event conditions about a year after the disturbance. Thus, the extent and manner of forest use tested in this study is in terms of ecological consequences an acceptable forest management tool.

\section{Zusammenfassung: Chemische Zusammensetzung der Fliessgewässer in Bergwaldeinzugsgebieten in den Bayerischen Alpen - Auswirkungen forstlicher Nutzung oder natürlicher Störungen}

In zwei Bergwaldeinzugsgebieten in den Bayerischen Alpen wurde die Zusammensetzung der Fliessgewässer untersucht. Niederschlag und Abfluss waren eng miteinander korreliert. Eingetragenes Wasser wurde jedoch im Ökosystem gespeichert und durch nachfolgende Niederschlagsereignisse ausgetauscht, so dass Pufferreaktionen ablaufen konnten. Darauf verweist der starke Austrag von Alkali- und Erdalkalikationen und Kieselsäure. Protonen, organischer Kohlenstoff, Stickstoff und organische wie anorganische Schadstoffe wurden im System angereichert.

In einem der Einzugsgebiete wurden nach zwei Jahren $40 \%$ des Bestandes plenterartig entnommen, um Informationen über die Auswirkungen von natürlichen oder anthropogenen Störungen auf die Stabilität dieser Ökosysteme zu erhalten. Abflussmenge und Austragsraten stiegen im ersten Jahr nach dem Eingriff stark an aufgrund eines Versauerungsschubes, erhöhter Mineralisierung und des Rückgangs der Aufnahme von Nährionen und Wasser. Mit Ausnahme von Nitrat gingen die Veränderungen im Chemismus der Fließgewässer ein Jahr nach dem forstlichen Eingriff 
wieder auf das Niveau der Vorlaufphase zurück. Ausmaß und Art der Holznutzung sind aus waldbaulicher wie ökologischer Sicht akzeptabel.

\section{Résumé: Composition chimique de l'eau de ruissel- lement dans la région des forêts montagneuses des Alpes bavaroises - effet des usages forestiers ou des perturbations naturelles}

L'étude porte sur la composition des eaux de ruissellement de deux bassins-versants forestiers montagneux des Alpes bavaroises. Il existe une étroite relation entre les précipitations et les décharges d'écoulement. Cependant, l'eau a été stockée pendant une longue période dans l'écosystème et a été échangée lors des chutes de pluie, ce qui a permis des actions de tamponnage de l'acidité. Ce processus est révélé par l'exportation riche en cations alkalins et et de terre alkaline, et en acide silicique. Des protons, du carbone organique, de l'azote et des polluants organiques et inorganiques se sont accumulés.

$40 \%$ du volume des racines des arbres ont été enlevés de l'un des bassins (patch cutting method) après une période d'étude de deux ans, afin de recueillir des informations sur les effets des perturbations naturelles ou d'origine humaine sur la stabilité de ces écosystè- mes. Pendant la première année après l'intervention, les décharges d'écoulement et les débits d'exportation augmentèrent fortement avec un accroissement de la minéralisation et de l'acidification, et une diminution de l'assimilation en nutriments et en eau. Les effets sont revenus à leur état initial environ un an après les perturbations, à l'exception du $\mathrm{NO}_{3}$. L'ampleur et la méthode des usages forestiers sont acceptables du point de vue de l'exploitation des forêts et des aspects écologiques.

PD Dr. Dr. Rupert Bäumler, Institute of Soil Science, Department of Ecology, TU München, D-85350 Freising-Weihenstephan.

e-mail:baeumler@wzw.tum.de

\section{Manuskripteingang/received/manuscrit entré le} 7.5.2002

Annahme zum Druck/accepted for publication/accepté pour l'impression: 20.9.2002 